第 19 回 日本臨床薬理学会 1998 年 11 月 20 21 日 別府

\title{
服薬指導を組み合わせた各種疾患別患者教室 「播磨病院市民講座」の試み
}

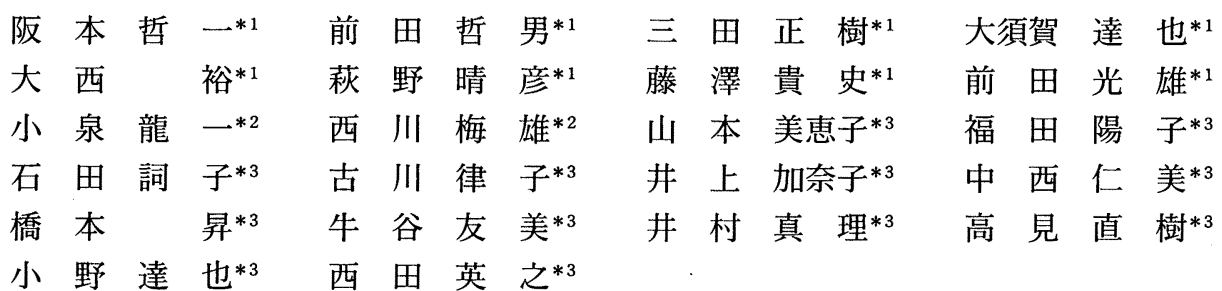

\section{目的}

近年の疾患、食事療法のみならす薬唷に对する 関心の高まりと服薬指導の義務化、薬唷賽の一部 自己負担化といった社会情乵が変化してきている。 この様な状況に対処し、当院では服薬指導を加え た各種疾患別患者教室を行っている。この集団患 者指導の試みについて報告する。

\section{方法}

平成 9 年度より毎年 4 回「播磨病院市民講座」 として各種疾患をテーマに患者教室を行っている。 高血圧、觜搭病、榶尿病、骨粗耘症の各教室にお いて、医師による各疾患についての雃義、栄美士 による各疾患の食事療法の講義及び看護㛿による 生活指導の輩義に加えて、薬郕師による講義「薬 の正しい服用の仕方」（薬の吸収のされ方、服用 の仕方等) と各疾患に用いられる菜削を実際に提 示説明 (集団的服薬指導) を行った。理解を深め て鿓う為、上記訸義内容に即したのパンフレット を作成し来られた方全員に配布した。参加自由の の患者教室とし、この間患者さんは出入り自由と し、終了した時点でおられた方にたいしてアンケ 一ト調査を行った。

*1 石川島播磨重工業健康保険組合播磿病院内科 于 678-0031 相生市旭 3-5-15

*2 石川島播磨重工業健康保険組合播磨病院整形外科

*3 石川島播磨重工業健康保除組合播磨病院薬郕科

\section{結果}

各疾患ごとに実際に使用されている当院の薬剤 を提示して説明を行う集団的服薬指導(Fig. 1)にお いては、実際に自分に処方されている薬绪と対比 することができ、患者さんたちには好評であった。

アンケート結果では医師及び薬抄師の講義及び パンフレットの理解度は $80 \%$ 以上は理解できて いた。また再度参加したいとの希㕵が90\%以上 を占めた。

\section{考察}

当院では平成 6 年 10 月より各科病棟総回䛦時 に薬郕師も同行しデイスカションに加わったり、 適宜医楽品情報提供をうけたりといった試みを通 して協力して治療を行う努力を進めている。また 平成 8 年より毎年 10 月 17 日から 23 日にかけ て行なわれている「薬と健康の週間」に合わせて 「薬はどうして効くのか」「薬の正しい服用の仕 方はどうなのか」といったことをテーマにした「や さしいお翻塆座」を内科と薬郕科が共同して開催 し個々の患者さんに対する服菜指導と平行して集 団的服薬指導を行っている。1）今回は更に具体 的に踏み込んで従来行なわれている集団患者指導 としての各種疾患別患者教室に菜刘師による集団 的服薬指導を加元、定期的に各疾患別に開催する 試みを行った。結果として多くの患者さんに聴䛨 してもらう事ができ、アンケート結果でも非常に 好評であった。 


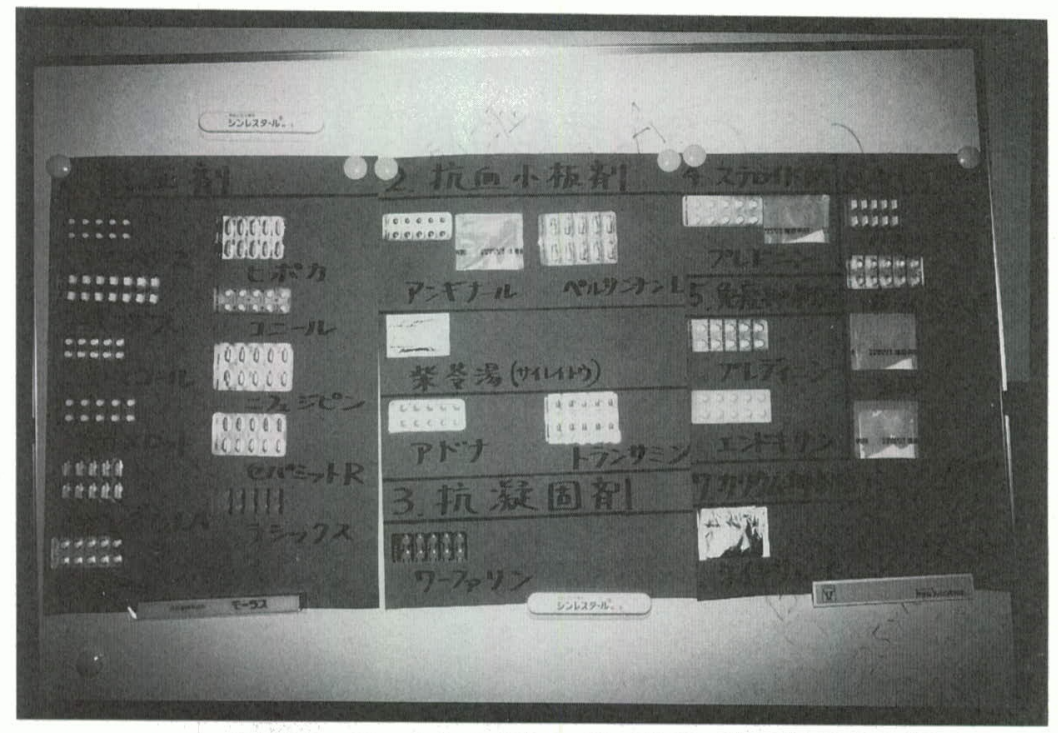

Fig.1 惄䐟病に用いられる薬珮の提示説明（集団的服薬指導）

(腎脿病教室にて)

この様な形㿟の患者教室では、患者さんのその 疾患の病癿、食事療法、生活指導に合わせて、薬 物療法と総合的に理解を進めることができるのみ ならず、医師・薬唷師をはじめ各部門の専門職の 協力のもとで治療がなされている事を理解してい ただく機会の一つとして非常に意義あるものと考 えられた。

今後ますます疾患の病㮩、食事療法、薬物療法 に関する関心が高まっていく事が予想され、この 様な試みは有用であったと思われた。

\section{文献}

1) 阪本哲一、三田正樹、中原贵子他：「薬と健 康の週間」に行った楽局前待合室での「やさしい お楽講座」の試み、臨床薬理、29(1, 2): $353-354(1998)$ 